\title{
Muscarinic blockade of methacholine induced airway and parenchymal lung responses in anaesthetised rats
}

\author{
M K Tulić, J L Wale, F Peták, P D Sly
}

\begin{abstract}
Background-It has previously been shown that $M_{1}$ cholinergic receptors are involved in the parenchymal response to inhaled methacholine in puppies using the $M_{1}$ selective antagonist pirenzepine. Although $M_{3}$ receptors are responsible for acetylcholine induced bronchoconstriction in isolated rat lung, the role of $M_{1}$ receptors has not been determined in the rat in vivo.
\end{abstract}

Methods-Anaesthetised, paralysed, open chested Brown Norway rats were mechanically ventilated and the femoral vein cannulated for intravenous injection of drugs. Low frequency forced oscillations were applied to measure lung input impedance $\left(Z_{L}\right)$ and computerised modelling enabled separation of $Z_{L}$ into airway and parenchymal components. Atropine $(500 \mu \mathrm{g} / \mathrm{kg}$ iv) and pirenzepine $(50,100$ or $200 \mu \mathrm{g} / \mathrm{kg}$ iv) were administered during steady state constriction generated by continuous inhalation $(1 \mathrm{mg} / \mathrm{ml})$ or intravenous (10 or $15 \mu \mathrm{g} / \mathrm{kg} / \mathrm{min}$ ) administration of methacholine.

Results-Continuous inhalation of methacholine produced a $185 \%$ increase in frequency dependent tissue resistance (G) which was effectively inhibited by atropine $500 \mu \mathrm{g} / \mathrm{kg}$ iv $(\mathrm{p}<0.01, \mathrm{n}=6)$. Pirenzepine $(50,100$ or $200 \mu \mathrm{g} / \mathrm{kg})$ had a minimal effect on the parenchymal response to inhaled methacholine. A $\mathbf{2 5 8 \%}$ increase in airway resistance (Raw) was induced by continuous intravenous infusion of methacholine and this response was effectively abolished by pirenzepine $(p<0.001, n=5)$. Cutting the vagi in the cervical region did not alter baseline airway mechanics. Vagotomy did not affect lung responses to intravenous methacholine nor the ability of pirenzepine to reduce these responses.

Conclusions-In the rat, $M_{1}$-subtype receptors are functional in airways but not in the tissue.

(Thorax 1999;54:531-537)

Keywords: forced oscillation technique; muscarinic blockade; lung parenchyma

Methacholine is commonly used as a challenge agent for the assessment of hyperresponsiveness in asthmatic subjects. It is a chemical analogue of acetylcholine and induces smooth muscle contraction by stimulating muscarinic cholinergic receptors located on the smooth muscle. In a number of animal studies the way in which methacholine alters lung function has been shown to depend on the route of delivery. Intravenous methacholine acts mainly on the airway producing an increase in airway resistance whereas inhaled methacholine alters the mechanical properties of both the airways and the lung tissues. ${ }^{1-3}$ One possible explanation for these findings is that different receptors are involved.

Muscarinic cholinergic receptors exist in at least four major subtypes that can be demonstrated pharmacologically. ${ }^{4}$ Multiple subtypes have, however, been identified biochemically in the lung and binding studies have shown the presence of $M_{1}, M_{2}$ and $M_{3}$ subtypes. ${ }^{5}$ A species difference in distribution of muscarinic receptors of the lung has been established. In isolated rat lung, stimulation of the $M_{3}$ receptor subtype is responsible for acetylcholine induced bronchoconstriction. ${ }^{7}$ However, previous experiments in our laboratory using alveolar capsules in puppies have shown that the peripheral lung responses to inhaled methacholine were antagonised by the $M_{1}$ selective blocker pirenzepine. ${ }^{8}$

Recent adaptations of the low frequency forced oscillatory technique in rodents have enabled us to partition lung function changes into airway and lung tissue components. ${ }^{1}$ Peripheral lung is a complex anatomical structure comprising bronchial wall (approximately $5 \%)$, vascular smooth muscle $(8 \%)$, and alveolar ducts and walls $(>86 \%)$ in rats. ${ }^{9}$ The present experiments were performed to investigate whether the peripheral lung responses to inhaled methacholine resulted from stimulation of muscarinic cholinergic receptors. Based on our previous findings in puppies, the role of $M_{1}$ receptors in airway and tissue responses to methacholine was also investigated by using the $\mathrm{M}_{1}$ selective antagonist pirenzepine. ${ }^{10}$

\section{Methods}

ANIMAL PREPARATION

Experiments were performed using adult male Brown Norway rats weighing $280-320$ g. The rats were anaesthetised by intramuscular injection of xylazine $(12 \mathrm{mg} / \mathrm{kg})$ and ketamine $(40 \mathrm{mg} / \mathrm{kg}$ ) and placed in the supine position. The trachea was exposed in the mid cervical region and cannulated with a metal catheter (internal diameter $2 \mathrm{~mm}$, length $1 \mathrm{~cm}$ ) and the animals were mechanically ventilated (Harvard Rodent Ventilator 683, MA, USA) with a tidal volume of $9 \mathrm{ml} / \mathrm{kg}$ and a frequency of 90 breaths/minute. The femoral veins were 


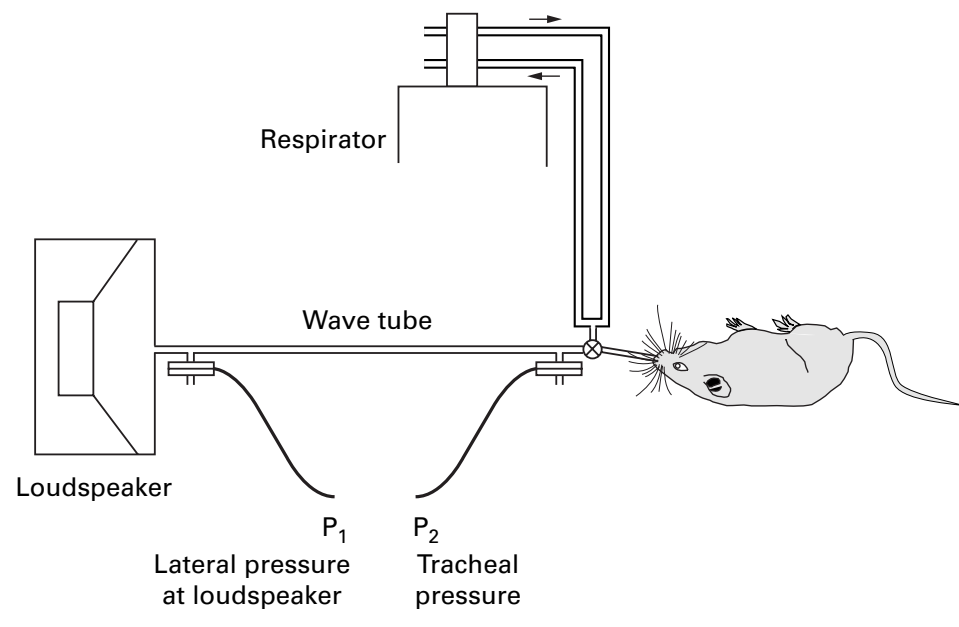

Figure 1 Schematic representation of the experimental set up. A loudspeaker is used to generate the low frequency forced oscillation signal which is delivered to the animal via a wave tube. Pressure is measured at each end of the wave tube and used to calculate the input impedance of the animal. The use of the wave tube obviated the need to measure flow in small animals. During measurements the ventilator is switched out of the circuit using a three-way tap.
Idaho, USA). Vagi were intact except in the third group of experiments where both right and left vagi were sectioned in the cervical region before baseline measurements and administration of intravenous methacholine and pirenzepine.

ESTIMATION OF AIRWAY AND PARENCHYMAL PARAMETERS

Lung input impedance $\left(Z_{L}\right)$ was measured using an adaptation of the low frequency forced oscillation technique in which pressure is measured at either end of a wave tube. ${ }^{1}$ The experimental set up is shown in fig 1. A threeway tap was used to switch the animal from the respirator to a loudspeaker-in-box system at end of expiration. The pressure in the box was set to $2.5 \mathrm{hPa}$ to keep the transpulmonary pressure constant during measurements. The loudspeaker generated a small amplitude pseudorandom signal (15 non-integer multiples between 0.5 and $21 \mathrm{~Hz}$ ) through a $120 \mathrm{~cm}$ long polyethylene wave tube with an internal diameter of $2 \mathrm{~mm}$. Two identical pressure transducers (ICS model 33NA002D) were used to measure the lateral pressures at the loudspeaker $\left(\mathrm{P}_{1}\right)$ and at the tracheal end $\left(\mathrm{P}_{2}\right)$ of the wave tube. The $\mathrm{P}_{1}$ and $\mathrm{P}_{2}$ signals were low pass filtered (5th order Butterworth, $25 \mathrm{~Hz}$ corner frequency) and sampled with an analogue to digital board of an IBM compatible $2.5 \mathrm{~cm} \mathrm{H}_{2} \mathrm{O}$ and the ribs were widely retracted.

Maintenance doses of anaesthetic and muscle relaxant were administered intravenously every 45 minutes. The electrocardiogram and heart rate were monitored continuously using limb leads connected to a standard electrocardiograph (78342A, Hewlett Packard Co,
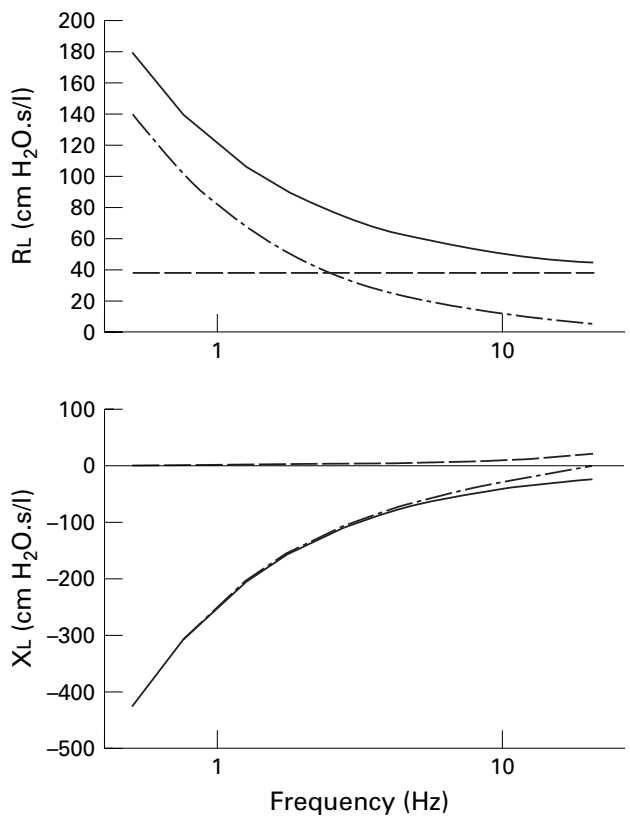

Figure 2 Schematic representation of the parameters derived from the constant phase model. The input impedance $\left(Z_{L}\right)$ is shown with solid lines. In the upper panel the real part of $Z_{L}$ (resistance) can be modelled as the combination of a frequency independent airway resistance (dashed line) and a frequency dependent tissue resistance (dash-dot line). In the lower panel the imaginary part of $Z_{L}$ (reactance) can be modelled as the combination of a frequency independent airway inertance (dashed line) and a frequency dependent tissue elastance (dash-dot line).
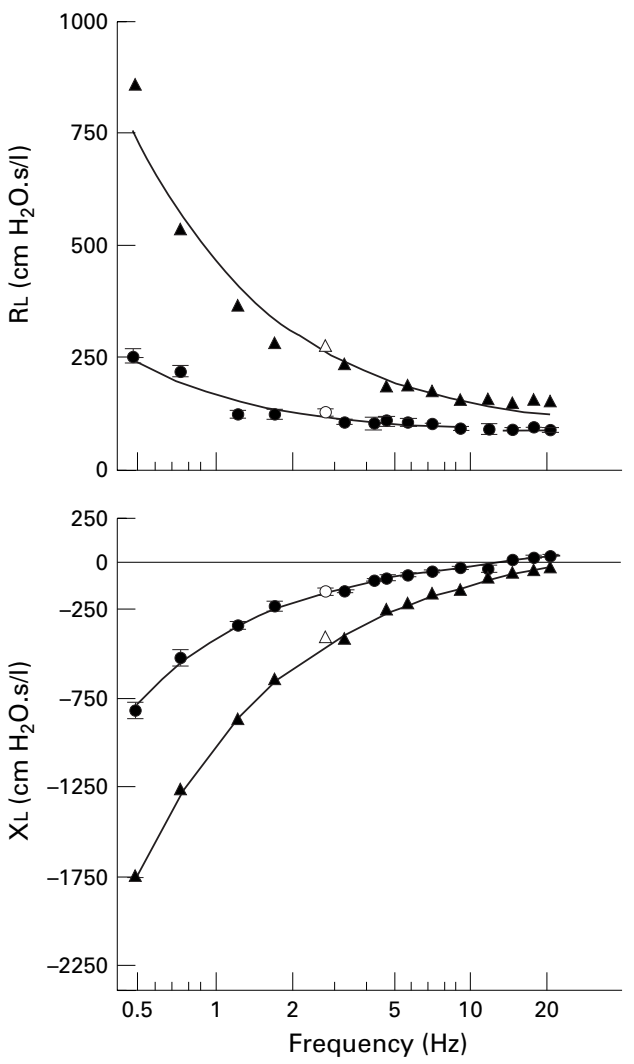

Figure 3 Real (lung resistance $R_{L}$ ) and imaginary (lung reactance $\left.X_{L}\right)$ parts of lung input impedance spectra $\left(Z_{L}\right)$ and the corresponding model fits in a single rat after inhalation of saline (ט) and methacholine $5 \mathrm{mg} / \mathrm{ml}(\mathbf{\Delta})$. With saline, values are given as mean (SE) of 4-6 successive $Z_{L}$ recordings. Following methacholine administration only the peak response is reported. Open symbols denote data points corrupted by cardiac noise and therefore omitted from the model fit. 

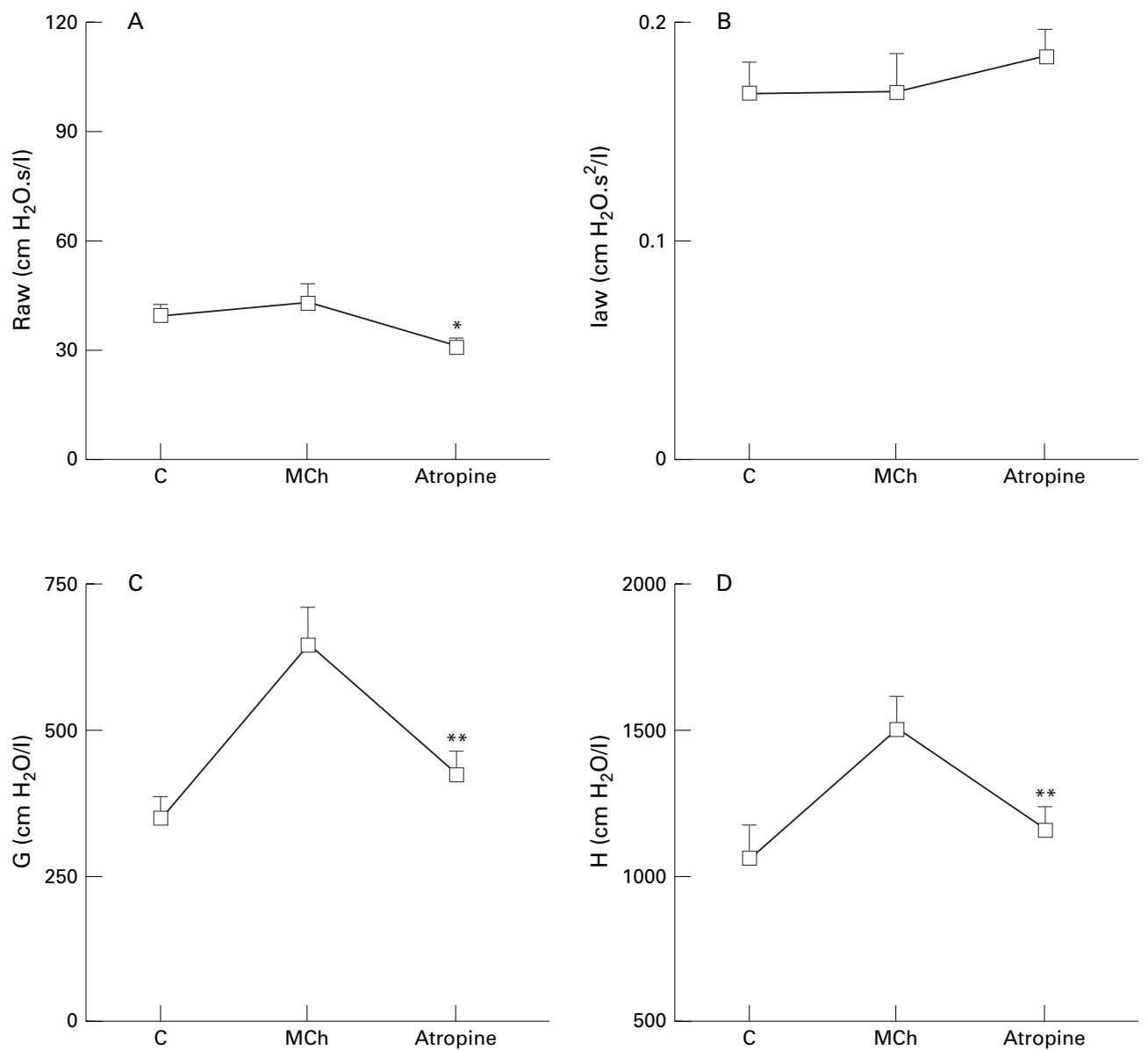

Figure 4 Effect of atropine sulphate (500 $\mu \mathrm{g} / \mathrm{kg}$ iv) on (A) airway resistance (Raw), (B) airway inertance (Iaw), (C) frequency dependent tissue resistance $(G)$, and $(D)$ tissue elastance $(H)$ during steady state response to inhaled methacholine $(1 \mathrm{mg} / \mathrm{ml})$ in anaesthetised rats with vagi intact. Results are given as mean (SE) of six animals. ${ }^{\star} p<0.05$, ${ }^{*} p<0.01$ versus methacholine response.

computer at a rate of $128 \mathrm{~Hz}$. Fast Fourier transformation with time windows of four seconds and $95 \%$ overlapping was used to calculate the pressure transfer functions $\left(\mathrm{P}_{1} / \mathrm{P}_{2}\right)$ from the six second long recordings. $\mathrm{Z}_{\mathrm{L}}$ was calculated as the load impedance of the wave tube using the following equation:

$\mathrm{ZL}_{\mathrm{L}}=\mathrm{Zo} \sinh (\gamma \mathrm{L}) /\left[\left(\mathrm{P}_{1} / \mathrm{P}_{2}\right)-\cosh (\gamma \mathrm{L})\right]$ where $\mathrm{L}$ is the length, $\mathrm{Zo}$ is the characteristic impedance, and $\gamma$ is the complex propagation wave number of the wave tube. The latter two parameters are determined by the geometrical data and the material constants of the tube wall and the air.

To separate the airway and parenchymal mechanics, a model containing a frequency independent airway resistance (Raw) and inertance (Iaw) in series with a constant phase tissue model including frequency dependent tissue resistance $(\mathrm{G})$ and tissue elastance $(\mathrm{H})$ was fitted to the $Z_{L}$ spectra by minimising the differences between the measured and modelled impedance values using the following equation:

$$
\mathrm{ZL}_{\mathrm{L}}=\mathrm{Raw}+\mathrm{j} \omega \mathrm{Iaw}+(\mathrm{G}-\mathrm{jH}) / \omega^{\alpha}
$$

where $j$ is the imaginary unit, $\omega$ is the angular frequency ( $2 \pi \mathrm{f})$, and $\alpha$, which is expressed as $\alpha$ $=2 / \pi \arctan (\mathrm{H} / \mathrm{G})$, which is not an independent parameter. Impedance points coinciding with the heart rate and its harmonics were omitted from the model fitting since cardiac activity caused low signal-to-noise ratio at these frequency components. A schematic representation of this model is shown in fig 2 .

RESPONSES TO METHACHOLINE

To standardise volume history the lungs were hyperinflated by superimposing two inspiratory cycles before starting measurements. Following 15 minutes of mechanical ventilation, baseline respiratory mechanics were measured by recording $4-6 \mathrm{ZL}_{\mathrm{L}}$ spectra. These were ensemble averaged and the model fitted to the average spectrum. Methacholine was then continuously administered in a concentration sufficient to increase frequency dependent tissue resistance $(\mathrm{G})$ by $50-100 \%$ at the steady state response.

\section{INHALED METHACHOLINE}

Methacholine was administered to the animal by inhalation at a concentration of $1 \mathrm{mg} / \mathrm{ml}$ using a jet nebuliser (LC PLUS, Pari-Werk $\mathrm{GmbH}$, Germany) driven by compressed air (5 $1 / \mathrm{min}$ ) into the inspiratory port of the respirator. This nebuliser delivers particles approximately $5 \mu \mathrm{m}$ in size (manufacturer's specifications). Steady state constriction was obvious after 8-12 minutes. 

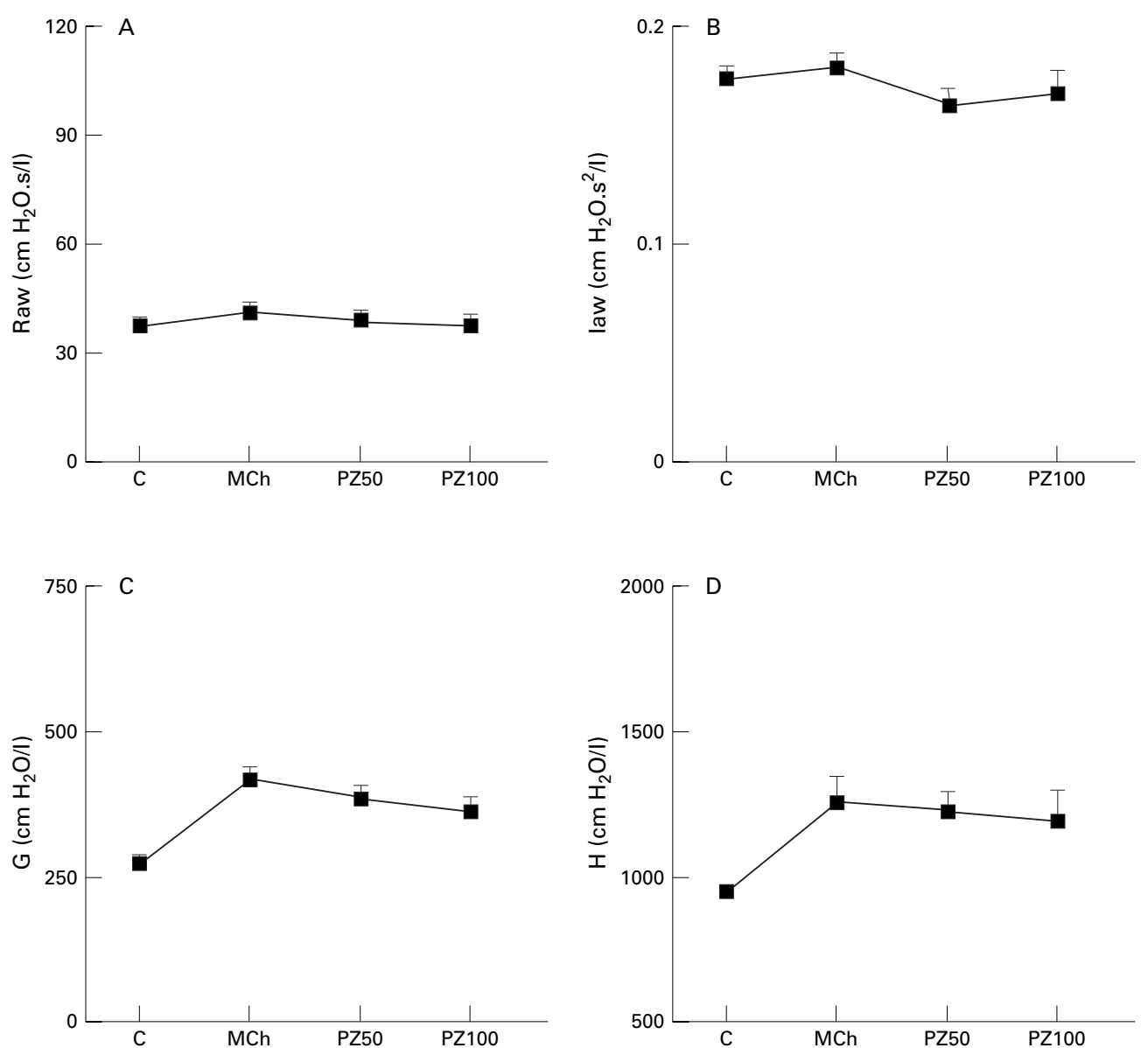

Figure 5 Effect of pirenzepine $50 \mu \mathrm{g} / \mathrm{kg}$ iv (PZ50) or $100 \mu \mathrm{g} / \mathrm{kg}$ iv (PZ100) on (A) airway resistance (Raw), (B) airway inertance (Iaw), (C) frequency dependent tissue resistance $(G)$, and (D) tissue elastance $(H)$ during steady state response to inhaled methacholine $(1 \mathrm{mg} / \mathrm{ml})$ in anaesthetised rats with vagi intact. Results are given as mean (SE) of five animals.

INTRAVENOUS METHACHOLINE

Methacholine was administered intravenously by continuous infusion at a rate of $10-15 \mu \mathrm{g} / \mathrm{kg} /$ min (Stoelting 220VAC, USA), sufficient to increase airway resistance (Raw) by approximately $100 \%$. Individual $Z_{L}$ curves were collected every two minutes until a plateau response was observed (approximately $15 \mathrm{~min}$ utes). These procedures resulted in a total methacholine administration time of 25-35 minutes.

RESPONSES TO MUSCARINIC ANTAGONIST

After the steady state response to methacholine had been established, the antagonist was administered by intravenous injection. After a period of two minutes individual $Z_{L}$ curves were collected also at two minute intervals. Atropine sulphate $(500 \mu \mathrm{g} / \mathrm{kg})$ was administered intravenously during the steady state response to inhaled methacholine. Pirenzepine was administered in cumulative doses of 50, 100 or $200 \mu \mathrm{g} / \mathrm{kg}$ at approximately $10-15$ minute intervals during steady state response to either inhaled or intravenous methacholine.

EFFECTS OF CERVICAL VAGOTOMY

In animals with the vagi cut, the effect of cumulative administration of pirenzepine (50, 100 , or $200 \mu \mathrm{g} / \mathrm{kg}$ ) during steady state constric- tion induced by intravenous methacholine was investigated following baseline measurements. The infused concentration of methacholine used to approximately double Raw was $10 \mu \mathrm{g} /$ $\mathrm{kg} / \mathrm{min}$ in four rats and $15 \mu \mathrm{g} / \mathrm{kg} / \mathrm{min}$ in one animal.

MATERIALS

Pirenzepine was kindly donated by Boehringer Mannheim GmbH (Mannheim, Germany); atropine sulphate and pancuronium bromide was purchased from Astra Pharmaceuticals (North Ryde, NSW, Australia); acetyl- $\beta$ methylcholine chloride (methacholine) was obtained from Sigma Chemical Company (St Louis, MO, USA); ketamine was purchased from Troy Laboratories (Smithfield, NSW, Australia); xylazine from Bayder (Pymble, NSW, Australia); and pentobarbitone sodium from Virbac (Peakhurst, NSW, Australia).

\section{STATISTICAL ANALYSIS}

Comparisons between groups were made on $\log$ transformed data using one way analysis of variance (ANOVA) with Student-NewmanKeuls correction for multiple comparisons. All results are expressed as mean (SE). $p$ values of $<0.05$ were regarded as statistically significant. 

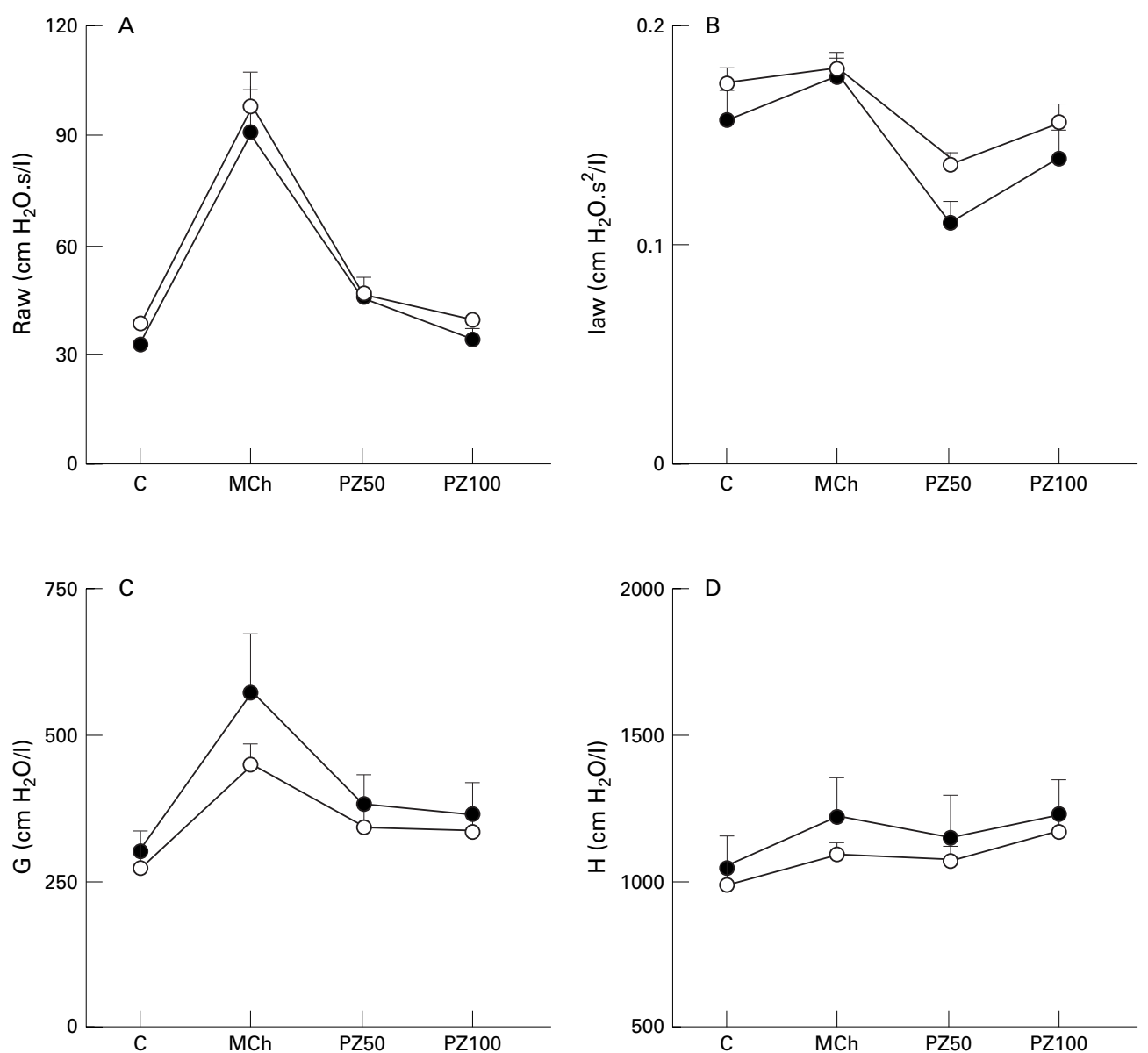

Figure 6 Effect of pirenzepine $50 \mu \mathrm{g} / \mathrm{kg}$ iv (PZ50) or $100 \mu \mathrm{g} / \mathrm{kg}$ iv (PZ100) on (A) airway resistance (Raw),

$(B)$ airway inertance (Iaw), (C) frequency dependent tissue resistance ( $G)$, and (D) tissue elastance $(H)$ during steady state response to intravenous methacholine $(10 \mathrm{mg} / \mathrm{kg} / \mathrm{min})$ in anaesthetised rats with vagi intact $(O, n=5)$ or vagi cut $(\bullet, n=5)$. Results are given as mean (SE).

\section{Results}

LUNG FUNCTION IN RESPONSE TO INHALED METHACHOLINE

Impedance spectra at baseline and after methacholine challenge are shown in fig 3. During steady state constriction induced by continuous inhalation of methacholine, frequency dependent tissue resistance (G) was increased by $185 \%$ above baseline $(p<0.01, n=6$; fig 4$)$. This increase in $G$ was associated with a similar $142 \%$ increase in tissue elastance $(\mathrm{H})(\mathrm{p}<0.01$, $\mathrm{n}=6$ ). Inhaled methacholine produced only minimal changes in airway resistance (Raw) and no change in airway inertance (Iaw) (fig 4).

EFFECT OF ATROPINE ON INHALED

METHACHOLINE

Following intravenous injection of atropine ( $500 \mu \mathrm{g} / \mathrm{kg}$ iv) parenchymal responses to inhaled methacholine were inhibited, significantly reducing $\mathrm{G}$ by $62 \%(\mathrm{p}<0.01, \mathrm{n}=6)$ and $\mathrm{H}$ by $77 \%$ $(\mathrm{p}<0.01, \mathrm{n}=6$; fig 4$)$. While $\mathrm{G}$ was still significantly above the baseline or control value after atropine treatment $(\mathrm{p}<0.001)$, tissue elastance $(\mathrm{H})$ returned to the baseline level after atropine administration. Despite the lack of effect of methacholine on Raw, intravenous injection of atropine significantly reduced the baseline airway tone by $20 \%(\mathrm{p}<0.05, \mathrm{n}=6)$. Little change was observed in Iaw with methacholine or atropine administration.
EFFECT OF PIRENZEPINE ON INHALED

METHACHOLINE

During steady state constriction induced by inhaled methacholine $G$ was increased by $153 \%$ above baseline $(\mathrm{p}<0.01, \mathrm{n}=5$; fig 5$)$ and was associated with a corresponding $132 \%$ increase in tissue elastance $(\mathrm{p}<0.05, \mathrm{n}=5)$. Once again, no change in Raw or Iaw was evident with inhaled methacholine. Pirenzepine $(50 \mu \mathrm{g} / \mathrm{kg}$ iv) produced no effect on parenchymal responses to methacholine (fig 5). Increasing the cumulative dose of pirenzepine to $100 \mu \mathrm{g} / \mathrm{kg}$ (fig 5) and $200 \mu \mathrm{g} / \mathrm{kg}$ (results not shown) produced no additional effect.

\section{LUNG FUNCTION IN RESPONSE TO INTRAVENOUS} METHACHOLINE: VAGI INTACT

The airway and tissue steady state responses to continuous intravenous infusion of mthacholine are shown in fig 6. Intravenous methacholine induced a marked and statistically significant increase in airway resistance of $258 \%$ above the baseline value $(p<0.001$, $\mathrm{n}=6$; fig 6A) and an increase of $165 \%$ in frequency dependent tissue resistance $(\mathrm{p}<0.01, \mathrm{n}=6$; fig $6 \mathrm{C})$. Intravenous administration of methacholine produced no effect on airway inertance (fig 6B) or tissue elastance (fig 6D). 
EFFECT OF PIRENZEPINE ON INTRAVENOUS METHACHOLINE: VAGI INTACT

Intravenous injection of pirenzepine $(50 \mu \mathrm{g} /$ $\mathrm{kg}$ ) resulted in a rapid decline in both the airway and tissue response to methacholine, reducing Raw by $76 \%(\mathrm{p}<0.001, \mathrm{n}=6)$ and $\mathrm{G}$ by $73 \%(\mathrm{p}<0.001, \mathrm{n}=6)$ from the plateau steady state methacholine response (fig 6). Iaw was significantly reduced by $21 \%$ below baseline $(\mathrm{p}<0.05, \mathrm{n}=6)$ and $\mathrm{H}$ remained unchanged (fig 6). The maximum effect on Raw and $G$ was evident within five minutes after administration and was maintained over the period of 15 minutes in which the response was observed.

Increasing the dose of pirenzepine to $100 \mu \mathrm{g} / \mathrm{kg}$ resulted in further reduction in airway resistance to $97 \%$ from plateau methacholine response or $3 \%$ above baseline $(\mathrm{p}<0.05, \mathrm{n}=6)$, completely abolishing the airway response to methacholine. Similarly, G was further reduced to $77 \%$ of the methacholine plateau response $(\mathrm{p}<0.001, \mathrm{n}=6$; fig $6)$. The response in $G$ was still significantly higher than the baseline response $(\mathrm{p}<0.05)$. Increasing the pirenzepine dose to $200 \mu \mathrm{g} / \mathrm{kg}$ iv (results not shown) did not result in further attenuation of the parenchymal responses to intravenous methacholine.

LUNG FUNCTION IN RESPONSE TO INTRAVENOUS METHACHOLINE: VAGI CUT

Cervical vagotomy produced no effect on baseline lung function parameters when compared with animals with vagi intact (fig 6). In the airway compartment a small reduction in the baseline Raw (15\%) in the rats with vagi cut failed to reach statistical significance. With the vagi cut, the airway response to intravenous methacholine was similar to that seen with the vagi intact (fig 6), with Raw increasing by $284 \%(\mathrm{p}<0.05, \mathrm{n}=5)$ above baseline. The same pattern of response was also seen for $G$ which increased by $191 \%$ from baseline $(\mathrm{p}<0.01, \mathrm{n}=5)$. In rats with cervical vagotomy only, minor but significant increases in Iaw $(12 \%)$ and $\mathrm{H}(16 \%)$ were apparent after methacholine administration (fig 6).

EFFECT OF PIRENZEPINE ON INTRAVENOUS

METHACHOLINE: VAGI CUT

Administration of pirenzepine in a dose of $50 \mu \mathrm{g} / \mathrm{kg}$ iv effectively reduced both the airway and the parenchymal response to intravenous methacholine, reducing Raw by $78 \%(\mathrm{p}<0.05$, $\mathrm{n}=5)$ and $\mathrm{G}$ by $67 \%(\mathrm{p}<0.05, \mathrm{n}=5)$ from the plateau steady state methacholine response. Pirenzepine in a dose of $50 \mu \mathrm{g} / \mathrm{kg}$ iv significantly reduced the baseline response in Iaw $(\mathrm{p}<0.01, \mathrm{n}=5)$ and $\mathrm{H}$ remained unchanged (fig 6). Increasing the dose of pirenzepine to $100 \mu \mathrm{g} / \mathrm{kg}$ further reduced Raw to $94 \%$ of the plateau response $(\mathrm{p}<0.001, \mathrm{n}=5)$ with no additional significant effect on $\mathrm{G}$ (fig 6). Pirenzepine $200 \mu \mathrm{g} / \mathrm{kg}$ (results not shown) did not produce any further effect. The pattern and time course of the pirenzepine response in animals with vagi cut was similar to the responses in animals with vagi intact.

\section{Discussion}

The results of these experiments in anaesthetised Brown Norway rats show that prolonged inhalation of methacholine results in a predominantly parenchymal (or tissue) constrictor response which is effectively reversed by a maximum dose of atropine sulphate but not by pirenzepine. In contrast, intravenous methacholine produced more marked changes in airway resistance which were reversed by pirenzepine.

Our adaptation of the low frequency forced oscillation technique allows lung mechanics to be partitioned into airway and parenchymal components by fitting the constant phase model to the impedance spectra. The airways through which gas moves by bulk flow will be included in the airway component, whereas airways through which gas moves by diffusion are likely to be included in the parenchymal component. It is therefore most likely that the parenchymal response is the result of contraction of smooth muscle in respiratory bronchioles and alveolar ducts and of contractile elements in the alveolar septa. These may be the contractile elements described by Kapanci et al. ${ }^{11}$ Vascular smooth muscle is present in the lung parenchyma but may be expected to relax in response to methacholine. ${ }^{12}$ Both atropine and cervical vagotomy tended to decrease Raw. Due to the variability, this reached statistical significance only for atropine. The lack of effect on baseline parenchymal measurements is consistent with cholinergic innervation being most dense in the large airways. ${ }^{13}$ Methacholine responses on airways were not altered by removing vagal tone.

Atropine is a non-selective muscarinic antagonist with very similar potency on all muscarinic receptor subtypes. ${ }^{14}$ It was effective in the present experiments in reducing the parenchymal responses to inhaled methacholine, confirming the role of muscarinic receptors in producing this response. A significant reduction in Raw was also apparent. Pirenzepine demonstrates relative selectivity for $M_{1}$ subtypes. $^{14}{ }^{15}$ In the present model pirenzepine inhibited the airway responses to intravenously administered methacholine but, unlike atropine, did not reduce the tissue responses to inhaled methacholine. The lowest dose of pirenzepine $(50 \mu \mathrm{g} / \mathrm{kg}$ iv) was approximately the $\mathrm{ED}_{50}$ dose, as reported by other workers measuring inhibition of the increased blood pressure with the $M_{1}$ selective agonist McN-A-343 in anaesthetised rats. ${ }^{15}$ In the present experiments pirenzepine reduced the airway response to intravenously infused methacholine by $76 \%$ and $78 \%$ in rats with vagi intact and severed, respectively. Pirenzepine $(100 \mu \mathrm{g} / \mathrm{kg}$ iv) had an almost maximal effect on the Raw to intravenous methacholine and yet, at this dose, there was no significant reduction in tissue responses to inhaled methacholine. It is therefore likely that pirenzepine is not antagonising $M_{3}$ receptors at these concentrations. As pirenzepine has a selectivity profile of $M_{1}>M_{4}, M_{3}>M_{2},{ }^{14}{ }^{15}$ it is also unlikely that it is acting on $\mathrm{M}_{2}$ receptors and one must conclude that we are observing an $M_{1}$ effect on 
Raw. Few $M_{1}$ subtype muscarinic receptors have been identified in rat lung using binding studies, ${ }^{56}$ and only $M_{2}$ and $M_{3}$ receptors were evident in the trachea and bronchi. ${ }^{6} \mathrm{Up}$ to $91 \%$ of muscarinic receptor protein in rat lung is of the $M_{2}$ subtype with $M_{3}$ receptor protein making up most of the remainder. ${ }^{8}$ The apparently small number of $\mathrm{M}_{3}$ receptors has, however, been reported to dominate muscarinic responses. ${ }^{7}$ It is therefore possible that a small number of $M_{1}$ receptors will still be sufficient to produce a physiological response.

Pirenzepine reversed the changes in both Raw and $\mathrm{G}$ when constriction was induced by intravenous methacholine. The increase in G with methacholine was not, however, associated with an increase in $\mathrm{H}$. Lutchen et $a l^{16}$ investigated this phenomenon using ventilation with gas mixtures of differing viscosities and densities. They explained the increase in $G$ as resulting from heterogeneous airway constriction. With this background we can interpret our results as follows. Pirenzepine competitively reverses the highly inhomogeneous constriction of the bronchial tree present following intravenous methacholine, therefore decreasing the inhomogeneities present in the periphery and producing a decrease in G. Taking into account the pirenzepine results when lung constrictor tone is induced either by aerosolised or intravenously administered methacholine, our data suggest that pirenzepine acts only on the airways since a decrease in $G$ was not evident when a purely parenchymal response to inhaled methacholine was generated.

$M_{1}$ receptors are understood to be associated with neuronal tissue to facilitate parasympathetic ganglionic transmission ${ }^{17}$ which, with the generalisation that autonomic innervation decreases down the respiratory tree, ${ }^{13}$ would agree with the purely airway effects observed in our experiments. They were also present in human alveolar walls in human lungs but not in the guinea pig. ${ }^{18}$ The ability of pirenzepine to reverse the airway responses to methacholine could be explained if methacholine resulted in a positive feedback, via ganglionic $M_{1}$ receptors, resulting in increased release of acetylcholine from cholinergic nerves. However, the fact that the same pattern of response was seen after bilateral cervical vagotomy makes this explanation unlikely. While caution must be exercised when extrapolating from the results of animal studies to humans, clinical studies have shown that pirenzepine improves lung function in both healthy subjects ${ }^{19}$ and asthmatics. ${ }^{20}$

In conclusion, the present experiments in anaesthetised rats show that, using lung impedance measurements, the non-selective muscarinic antagonist atropine reverses the increase in parenchymal resistance produced by prolonged inhalation of methacholine. The $M_{1}$ selective muscarinic antagonist pirenzepine had no significant effect on parenchymal responses to inhaled methacholine and reversed airway responses to intravenously administered methacholine. Cutting the cervical vagi did not alter resting lung function or responses to methacholine and pirenzepine. It therefore appears that, in the rat, $M_{1}$ subtype receptors are functionally present in the airways but could not be demonstrated in the parenchyma.

This study was supported by a grant from the National Health and Medical Research Council, Australia and an Australian Lung Foundation, Smith Kline and Beecham Award. M K Tulić is holding an Asthma Foundation of Western Australia Postgraduate PhD Scholarship.

1 Peták F, Hantos Z, Adamicza Á, et al. Methacholine-induced bronchoconstriction in rats: effects of intravenous vs aerosol delivery. F Appl Physiol 1997;82:1479-87.

2 Sly PD, Lanteri CJ. Differential responses of the airways and pulmonary tissues to inhaled histamine in young dogs. $\mathcal{F}$ Appl Physiol 1993;68:1562-7.

3 Sly PD, Lanteri CJ. Partitioning of pulmonary responses to inhaled methacholine in puppies. F Appl Physiol 1991;71: 886-91.

4 Eglen RM, Hegde SS, Watson W. Muscarinic receptor subtypes and smooth muscle function. Pharmacol Rev 1996;48:531-65.

5 Gies JP, Bertrand C, Vanderheyden P, et al. Characterization of muscarinic receptors in human, guinea pig and rat lung. 7 Pharmacol Exp Ther 1989;250:309-15.

6 Fryer AD, El Fakahany EE. Identification of three muscarinic receptor subtypes in rat lung using binding studies with selective antagonists. Life Sci 1990;47:611-8.

7 Post MJ, Te Biesebeek JD, Doods HN, et al. Functional characterization of the muscarinic receptor in rat lungs. Eur f Pharmacol 1991;202:67-72.

8 Sly PD, Willet KE, Kano S, et al. Pirenzepine blunts the pulmonary parenchymal response to inhaled methacholine. Pulm Pharmacol 1995;8:123-9.

9 Ludwig MS, Dallaire MJ. Structural composition of lung parenchymal strip and mechanical behaviour during sinusoidal oscillation. f Appl Physiol 1994;77:2029-35.

10 Hammer R, Giachetti A. Muscarinic receptor subtypes: $M_{1}$ and $M_{2}$. Biochemical and functional characterization. Life Sci 1982;31:2991-8.

11 Kapanci Y, Assimacopoulos A, Irle C, et al. Contractile interstitial cells in pulmonary alveolar septa: a possible regulator of ventilation/perfusion ratio? Ultrastructural mmunofluorescence and in vitro studies. F Cell Biol 1974; 60:375-92.

12 Barnes PJ. Modulation of neurotransmission in airways. Physiol Rev 1992;72:699-729.

13 Richardson JB. Nerve supply to the lungs. Am Rev Respir Dis 1979;119:785-802.

14 Doods HN, Entzeroth M, Ziegler H, et al. Pharmacological profile of selective muscarinic receptor antagonists on guinea-pig ileal smooth muscle. Eur f Pharmacol 1994;253: 275-81.

15 Eberlein WG, Engel W, Mihm G, et al. Structure-activity relationships and pharmacological profile of selective tricyclic antimuscarinics. Trends Pharmacol Sci 1989;Suppl IV clic antimuscarinics. Trends Pharmacol Sci
(Subtypes of muscarinic receptors):50-4.

16 Lutchen KR, Hantos Z, Peták F, et al. Airway inhomogeneities contribute to apparent lung tissue mechanics during constriction. F Appl Physiol 1996;80:1841-9.

17 Barnes PJ. Muscarinic receptor subtypes in airways. Life Sci 1993;52:521-7.

18 Mak JCW, Barnes PJ. Autoradiographic visualization of muscarinic receptor subtypes in human and guinea pig lung. Am Rev Respir Dis 1990;141:1559-68.

19 Cazzola M, Russo S, DeSantis D, et al. Respiratory responses to pirenzepine in healthy subjects. Int 7 Clin Pharmacol 1987;25:105-9.

20 Sertl K, Meryn S, Graninger W, et al. Acute effects of pirenzepine on bronchospasm. Int $\mathcal{F}$ Clin Pharmacol Therapy Toxicol 1986;24:655-7. 